\title{
Effect of Incremental Urea Supplementation of a Conventional Corn Silage-Based Diet on Ruminal Ammonia Concentration and Synthesis of Microbial Protein ${ }^{1}$
}

\author{
S. E. Boucher, ${ }^{\star}$ R. S. Ordway, † N. L. Whitehouse, ${ }^{*}$ F. P. Lundy, † P. J. Kononoff,§ and C. G. Schwab*2 \\ *Department of Animal and Nutritional Sciences, University of New Hampshire, Durham 03824 \\ †Blue Seal Feeds Inc., Sandy Creek, NY 13145 \\ łFeed Analysis Consortium Inc., Homer, NY 13077 \\ §Department of Animal Science, University of Nebraska-Lincoln, Lincoln 68583
}

\section{ABSTRACT}

One primiparous and 3 multiparous lactating Holstein cows fitted with ruminal and duodenal cannulas were used in a $4 \times 4$ Latin square design to determine the efficacy of adding urea to a corn silage-based diet on ruminal fermentation and microbial protein synthesis. Dietary treatments were $0,0.3,0.6$, and $0.9 \%$ urea in diet dry matter (DM); urea was manually top dressed and incorporated into the ration. The basal diet contained (DM basis) $52 \%$ forage (with $61 \%$ of forage provided as corn silage) and $48 \%$ concentrate ingredients. The basal diet was formulated to meet National Research Council (NRC, 2001) requirements for energy and all nutrients except rumen-degradable protein (RDP) and metabolizable protein. Experimental periods lasted $14 \mathrm{~d}$ with the first $9 \mathrm{~d}$ for adaptation. The basal diet, without urea addition, contained 9.2\% RDP in DM and had a predicted RDP balance of $-167 \mathrm{~g} / \mathrm{d}$ (NRC, 2001). There were no effects of dietary treatment on ruminal true digestibility of organic matter or ruminal apparent digestibility of neutral detergent fiber and acid detergent fiber. Total ruminal volatile fatty acid concentrations increased linearly with increasing urea level. Feeding increasing amounts of urea quadratically increased rumen ammonia $\mathrm{N}$ concentrations $(9.0,11.9$, 12.8 , and $17.4 \mathrm{mg} / \mathrm{dL}$ at $0,0.3,0.6$, and $0.9 \%$ urea supplementation, respectively), passage of microbial $\mathrm{N}$, and microbial $\mathrm{N}$ in duodenal digesta as a percentage of nonammonia $\mathrm{N}$. The results of this study indicate that there were some positive effects of adding urea to the described lactating dairy cow diet, and that microbial protein synthesis was maximized at an average

Received January 8, 2007.

Accepted August 10, 2007.

${ }^{1}$ This is Scientific Contribution Number 2321 from the New Hampshire Agricultural Experiment Station.

${ }^{2}$ Corresponding author: charles.schwab@unh.edu ruminal ammonia $\mathrm{N}$ concentration of $12.8 \mathrm{mg} / \mathrm{dL}$ when urea was added at $0.6 \%$ in diet DM.

Key words: lactating cow, urea, microbial protein, ammonia $\mathrm{N}$

\section{INTRODUCTION}

Corn silage continues to be the primary forage fed to lactating dairy cows in the Northeast region of the United States and is growing in popularity in other parts of the country. Corn silage is an excellent forage for lactating cows because of its high content of digestible energy. However, corn silage contains considerably less RDP compared with other high quality forages (NRC, 2001). Consequently, the use of corn silage may require greater supplementation of diets with RDP. Urea has long been known to be a successful replacement for some of the degradable true protein in corn silage based diets (Holter et al., 1968; Van Horn et al., 1969).

Maximizing ruminal synthesis of microbial protein is considered beneficial because the AA profile of microbial protein is believed to more closely match the required profile of AA by the host animal than most feed proteins (NRC, 2001). Rumen microorganisms meet their $\mathrm{N}$ requirements for protein synthesis from the mixture of ammonia, free AA, and peptides that is released as a result of microbial degradation of dietary $\mathrm{RDP}$ and recycled $\mathrm{CP}$. The specific requirements of mixed populations of rumen microbes for ammonia, AA, and peptide $\mathrm{N}$ for maximal synthesis of microbial protein and fermentation of the diet have yet to be defined (Jones et al., 1998). Matching the supply of rumendegradable $\mathrm{N}$ sources with the quantity required by rumen microbes will maximize the capture of the degradable $\mathrm{N}$ as microbial protein (NRC, 2001).

Much research has been dedicated to defining the optimum ruminal ammonia $\mathrm{N}$ concentration for maximal synthesis of microbial protein (Hume et al., 1970; 
Table 1. Ingredient composition of $\mathrm{TMR}^{1}$

\begin{tabular}{|c|c|c|c|c|}
\hline \multirow[b]{2}{*}{ Ingredient (\% of DM) } & \multicolumn{4}{|c|}{ Treatment (\% urea, DM basis) } \\
\hline & 0.0 & 0.3 & 0.6 & 0.9 \\
\hline Corn silage & 32.1 & 32.0 & 32.0 & 32.0 \\
\hline Mixed, mostly grass silage & 16.0 & 16.0 & 16.0 & 16.0 \\
\hline Alfalfa hay & 4.0 & 4.0 & 4.0 & 4.0 \\
\hline Barley grain, rolled & 6.0 & 6.0 & 6.0 & 6.0 \\
\hline Corn grain, fine grind, dried & 19.1 & 19.0 & 19.0 & 19.0 \\
\hline Soybean hulls & 4.5 & 4.5 & 4.4 & 4.4 \\
\hline Citrus pulp, dried & 3.0 & 3.0 & 3.0 & 3.0 \\
\hline Beet sugar pulp, dried & 3.0 & 3.0 & 3.0 & 3.0 \\
\hline Soybean meal, $48 \% \mathrm{CP}$ & 6.6 & 6.6 & 6.6 & 6.5 \\
\hline Blood meal, ring-dried & 1.0 & 1.0 & 1.0 & 1.0 \\
\hline Feather meal & 0.3 & 0.3 & 0.3 & 0.3 \\
\hline Urea & 0.0 & 0.3 & 0.6 & 0.9 \\
\hline Megalac $^{2}$ & 1.7 & 1.7 & 1.7 & 1.7 \\
\hline Mineral and vitamin $\operatorname{mix}^{3}$ & 2.7 & 2.7 & 2.7 & 2.7 \\
\hline
\end{tabular}

${ }^{1}$ Diets contained $0.6 \%$ sepiolite, but the sepiolite is not included in the above description of the diets because it has no nutritive value and is not included in the reported intakes of DM.

${ }^{2}$ Church and Dwight Co. Inc., Princeton, NJ.

${ }^{3}$ Contained (as-fed basis) $29.95 \%$ sodium sesquicarbonate, $13.65 \%$ calcium carbonate, $15.25 \%$ salt, $12.41 \%$ magnesium oxide, $12.41 \%$ calcium sulfate, $5.78 \%$ monosodium phosphate, $3.09 \%$ trace mineral and vitamin premix, $4.60 \%$ yeast culture (Diamond V XP, Diamond Mills, Inc., Cedar Rapids, IA), and 1.05\% MTB100 (Alltech, Inc., Nicholasville, KY), 1.81\% Zinpro 4-plex (Zinpro Corp., Eden Prairie, $\mathrm{MN})$. The trace mineral and vitamin premix contained) $292 \mathrm{kIU} / \mathrm{kg}$ of vitamin A, $67 \mathrm{kIU} / \mathrm{kg}$ of vitamin D, 1,122 IU/kg of vitamin $\mathrm{E}, 10.5 \%$ $\mathrm{Ca}, 1.3 \% \mathrm{P}, 7.5 \% \mathrm{Mg}, 0.02 \% \mathrm{~K}, 2.45 \% \mathrm{~S}, 10 \mathrm{mg} / \mathrm{kg}$ of Se, $1,794 \mathrm{mg} /$ $\mathrm{kg}$ of $\mathrm{Mn}, 2,135 \mathrm{mg} / \mathrm{kg}$ of $\mathrm{Zn}, 1,104 \mathrm{mg} / \mathrm{kg}$ of Fe, $378 \mathrm{mg} / \mathrm{kg}$ of $\mathrm{Cu}, 64$ $\mathrm{mg} / \mathrm{kg}$ of $\mathrm{Mo}, 9.2 \% \mathrm{Cl}$, and $6.0 \% \mathrm{Na}$.

Satter and Slyter, 1974; Slyter et al., 1979; Kang-Meznarich and Broderick, 1981) and maximum rates of ruminal digestion of feed (Hume et al., 1970; Mehrez et al., 1977; Kang-Meznarich and Broderick, 1981; Erdman et al., 1986; Odle and Schaefer, 1987). Reported ruminal ammonia $\mathrm{N}$ concentrations considered optimum to support maximum synthesis of microbial protein and rate of ruminal fermentation range from 2 to $13 \mathrm{mg} / \mathrm{dL}$ and from 3 to $25 \mathrm{mg} / \mathrm{dL}$, respectively. The experimental units (fermentors in continuous culture, sheep, steers, and nonlactating cows), diets, and methods for increasing ammonia $\mathrm{N}$ concentrations (e.g., urea infusion, ammonium acetate fed hourly, etc.) varied in these studies, which could explain the discrepancies in the reported values. In addition, to our knowledge, the optimal ruminal ammonia $\mathrm{N}$ concentration for maximum synthesis of microbial protein or for maximum ruminal digestion of feed has not been determined in lactating cows fed conventional diets supplemented with urea.

Because of the variation in reported values for optimal ruminal ammonia $\mathrm{N}$ concentrations and the lack of studies involving lactating dairy cows fed conventional diets formulated to meet nutrient requirements for lactation, a better understanding of the relationships between ruminal ammonia $\mathrm{N}$ concentrations and ruminal fermentation in lactating cows is needed. The objective of this study was to determine if there was a benefit to ruminal fermentation by adding urea to a conventional corn silage-based diet fed to lactating dairy cows, and if so, to determine the mean ruminal ammonia $\mathrm{N}$ concentration that was required to maximize microbial protein synthesis, digestibility of diet $\mathrm{OM}$, and rates of ruminal degradation of selected feedstuffs.

\section{MATERIALS AND METHODS}

\section{Experimental Design and Treatment Diets}

Two multiparous and 2 primiparous Holstein cows previously fitted with ruminal and duodenal cannulas were assigned to 1 of 4 treatments in a $4 \times 4$ Latin square design. After the first period of the experiment, one of the primiparous cows went off feed and was replaced with another cannulated multiparous cow for periods 2 to 4 . Dietary treatments were $0,0.3,0.6$, and $0.9 \%$ urea in diet DM. Dietary urea treatments were weighed using sepiolite as an inert carrier. Urea and sepiolite were weighed separately in the laboratory and then combined and mixed thoroughly. Sepiolite was included at a rate of $0.6 \%$ of diet DM, regardless of treatment level. Urea/sepiolite mixtures were top dressed and manually incorporated into the TMR at each feeding. All cows were fed the same basal diet (Table 1) that was formulated to be deficient in RDP $(-167 \mathrm{~g} / \mathrm{d}$; NRC, 2001) when urea was not added to the $\operatorname{diet}$ (Table 2).

The cows originally assigned to the study were 203 to 228 DIM at the beginning of the experiment. The cow that was assigned to the study at the beginning of the second period was 19 DIM. Experimental periods were $14 \mathrm{~d}$ with a 9 -d adaptation. The basal diet was fed 3 wk before the start of the study to adapt the cows to this diet.

Intakes of DM were calculated daily, and amounts of dietary treatments were adjusted based on level of DMI on d 3, 6, and 10 of each experimental period. Cows were fed in individual feed tubs that were closed before feeding and remained closed until the treatments were thoroughly mixed into the TMR.

\section{Management and Feeding}

All procedures related to animal care were conducted with the approval of the University of New Hampshire Institutional Animal Care and Use Committee. Cows were housed in a naturally ventilated tie-stall barn. Cows were milked and fed 3 times daily at 8-h intervals $(0500,1300$, and $2100 \mathrm{~h})$. Cows were fed $20 \%$ of their total daily feed allotment at $0500 \mathrm{~h}, 50 \%$ at $1300 \mathrm{~h}$, and $30 \%$ at $2100 \mathrm{~h}$ for ad libitum feed intake. The basal 
Table 2. NRC (2001) evaluation of consumed diets

\begin{tabular}{lcccc}
\hline & \multicolumn{4}{c}{ Treatment (\% urea, DM basis) } \\
\cline { 2 - 5 } Item $^{1}$ & 0.0 & 0.3 & 0.6 & 0.9 \\
\hline NDF, \% of DM & 35.9 & 35.8 & 35.7 & 35.6 \\
Forage NDF, \% of DM & 26.4 & 26.3 & 26.2 & 26.1 \\
ADF, \% of DM & 22.3 & 22.3 & 22.2 & 22.1 \\
NFC, \% of DM & 41.6 & 40.9 & 40.2 & 39.6 \\
Ether extract, \% of DM & 4.5 & 4.5 & 4.5 & 4.5 \\
DCAD, mEQ/kg & 393 & 392 & 391 & 390 \\
NE, Mcal/kg of DM & 1.61 & 1.61 & 1.60 & 1.60 \\
NE L required, Mcal/d & 32.4 & 29.3 & 32.3 & 31.3 \\
NE supplied, Mcal/d & 33.3 & 32.6 & 33.5 & 33.9 \\
Mcal/d balance, Mcal/d & 0.9 & 3.2 & 1.2 & 2.6 \\
MP required, g/d & 2,195 & 1,951 & 2,157 & 2,098 \\
MP supplied, g/d & 2,056 & 2,089 & 2,159 & 2,185 \\
MP balance, g/d & -139 & 138 & 3 & 87 \\
DM intake, actual, kg/d & 20.7 & 20.2 & 20.9 & 21.2 \\
DM intake, predicted, kg/d & 23.3 & 21.8 & 23.4 & 22.8 \\
NE Lallowable milk, kg/d & 35.3 & 34.7 & 35.5 & 36.3 \\
MP allowable milk, kg/d & 30.6 & 32.9 & 33.8 & 34.4 \\
Actual milk, kg/d & 33.9 & 29.6 & 33.7 & 32.3 \\
CP, \% of DM & 14.9 & 15.7 & 16.5 & 17.3 \\
RDP, \% of DM & 9.2 & 10.0 & 10.8 & 11.6 \\
RUP, \% of DM & 5.7 & 5.7 & 5.7 & 5.7 \\
RDP balance, g/d & -167 & 8 & 179 & 356 \\
RUP balance, g/d & -178 & 177 & 3 & 112 \\
RDP balance, \% & 92 & 100 & 109 & 117 \\
RUP balance, \% & 88 & 118 & 100 & 110 \\
\hline
\end{tabular}

${ }^{1}$ Values predicted from diets fed to animals and animal inputs from each treatment.

diet (Table 1) was fed as a TMR and was prepared by weighing each ingredient and mixing in a mobile drum mixer (Data Ranger; American Calan Inc., Northwood, $\mathrm{NH})$. The basal diet was prepared using fresh feed before each feeding. Feed offered was adjusted daily to achieve 5 to $10 \%$ orts. Orts were collected and weighed daily at $1100 \mathrm{~h}$. Cows were milked in a milking parlor with automatic take-offs and milk meters. Milk weights were recorded at each milking. Cows were weighed on 2 consecutive days in the middle and at the end of the study. Two independent scorers assigned BCS in the middle and at the end of the study. The BW and BCS (mean $\pm \mathrm{SD}$ ) were $668 \pm 93 \mathrm{~kg}$ and $3.56 \pm 0.18$, respectively.

Chromium oxide $\left(\mathrm{Cr}_{2} \mathrm{O}_{3}\right)$ was used as a digesta flow marker for estimating passage of DM to the small intestine. Seven grams of $\mathrm{Cr}_{2} \mathrm{O}_{3}$ (C333-3, Fisher, Fair Lawn, $\mathrm{NJ})$ was weighed into 28 -g porcine gelatin capsules (Torpac, Fairfield, NJ) and dosed 3 times daily. Capsules were placed into the middle of the rumen mat by inserting a balling gun into a slit cut into the stopper of the ruminal cannula at 0500,1300 , and $2100 \mathrm{~h}$. Chromium oxide was dosed beginning $3 \mathrm{~d}$ before the start of the experiment and continued daily throughout the experiment.

\section{Feed Sampling and Analysis}

For adjustment of daily feed offered and adjustment of dietary treatments, samples of silage, TMR, and orts were collected Sunday through Friday. Composites of each sample were made twice weekly to determine DM using a microwave oven (R-209HK, Sharp, Mahwah, NJ) and particle size distribution using the Penn State Particle Separator (Heinrichs, 1996).

In addition, silages and concentrates were sampled on $1 \mathrm{~d}$ during each of the 4 sample collection weeks for nutrient analysis. Alfalfa hay was sampled via core sampling upon delivery (approximately 2 mo before the start of the experiment). Silages were dried to an approximate $88 \% \mathrm{DM}$ in a forced hot air oven at $60^{\circ} \mathrm{C}$ to minimize the loss of volatiles, and the concentrate feed ingredients were dried at $60^{\circ} \mathrm{C}$ for $6 \mathrm{~h}$ (VWR Scientific, West Chester, PA). The dried silages and concentrate feeds were allowed to equilibrate to room temperature $\left(23^{\circ} \mathrm{C}\right)$, and then were ground to pass a $1-\mathrm{mm}$ screen using a Wiley mill (Thomas Scientific, Swedesboro, NJ). Composites were made of each dried feed across periods and analyzed for $\mathrm{DM}, \mathrm{NDF}, \mathrm{ADF}$, neutral detergent insoluble CP, acid detergent insoluble CP, CP, fat, NSC, starch, ash, and minerals (Table 3 ) using wet chemistry (Dairy One DHI Forage Testing Laboratory, Ithaca, NY). Nonfiber carbohydrate (NFC; Table 3) was calculated by difference: $100-[\mathrm{CP}+(\mathrm{NDF}-$ neutral detergent insoluble $\mathrm{CP})+$ fat + ash] .

All required animal and feed data were entered into the NRC (2001) model to determine the chemical composition of the basal diet and its nutritional adequacy (Table 2). Model default values were used for the $\mathrm{N}$ fractions, the digestion rates of fraction $B$ (except for corn silage, ground corn, and soybean meal (SBM), which were determined in situ), RUP digestibility, and processing adjustment factors. Actual average lactation number, DMI, DIM, days pregnant, BW, BCS, milk yield, and milk components were inputted.

\section{Duodenal, Rumen, Blood, and Milk Sampling}

Duodenal samples were taken every $6 \mathrm{~h}$ on d 9 to 12 of each experimental period for a total of 16 samples per cow per period. Sampling began $1.5 \mathrm{~h}$ later on each successive sampling day so that the 16 samples represented every $1.5 \mathrm{~h}$ of a 24 -h day. The first $500 \mathrm{~mL}$ of a sample was discarded and the next $1,000 \mathrm{~mL}$ was collected. Samples were pooled per cow per period upon collection and stored frozen $\left(-10^{\circ} \mathrm{C}\right)$. The frozen composite samples were thawed at the end of each experimental period and homogenized using a 3.8-L commercial blender (Waring Products Division, New Hartford, CT). Four subsamples of each composite were collected. Two of the subsamples were lyophilized (Labconco, Kansas 
Table 3. Chemical composition of consumed feeds

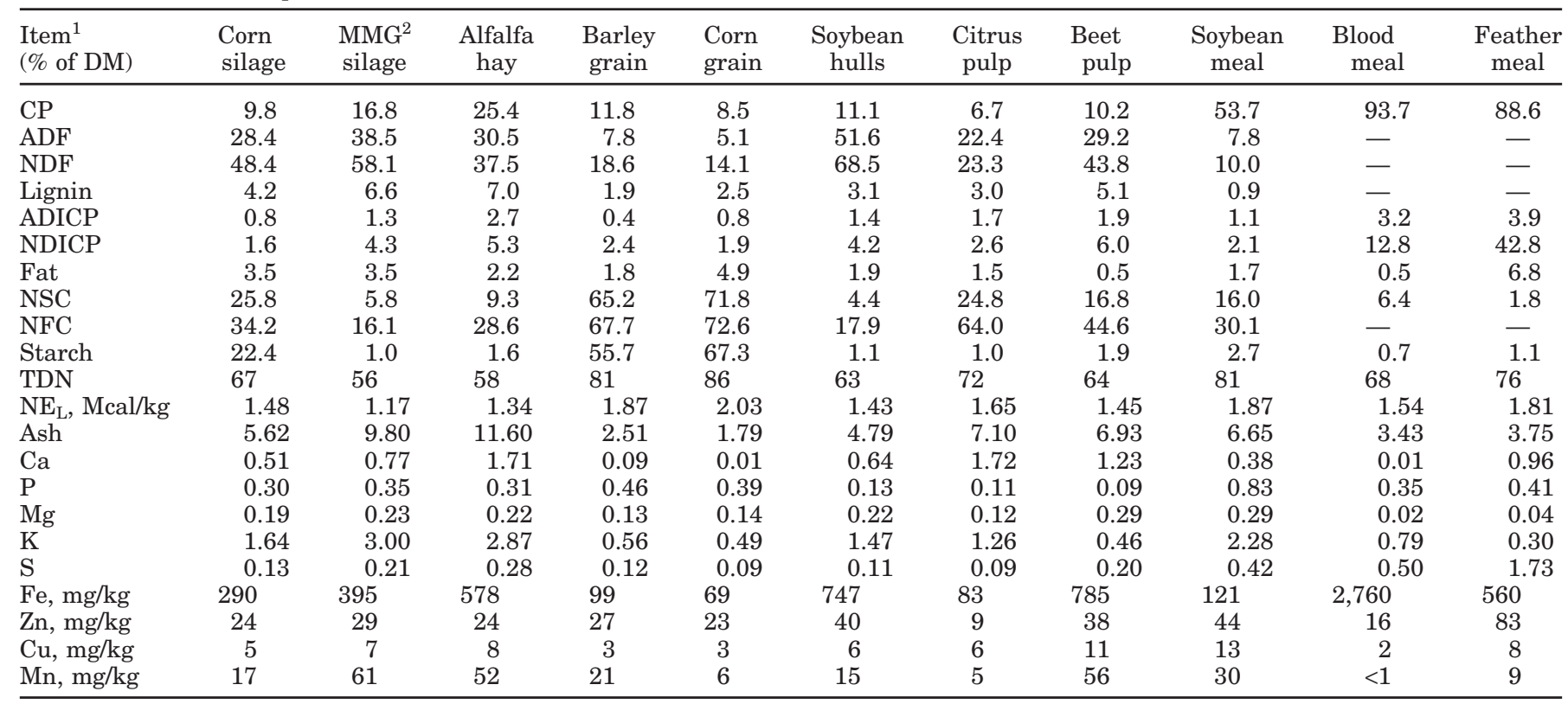

${ }^{1} \mathrm{ADICP}=$ acid detergent insoluble $\mathrm{CP}$; NDICP = neutral detergent insoluble CP; TDN = total digestible nutrients.

${ }^{2} \mathrm{MMG}=$ mixed, mostly grass.

City, MO) for $56 \mathrm{~h}$, and the other 2 subsamples were frozen for analysis of ammonia.

Rumen fluid was sampled concurrent with duodenal sampling. Rumen fluid was collected by inserting a polyvinyl chloride pipe (i.d. $=1.3 \mathrm{~cm}$ ) into the slit of the ruminal cannula stopper and applying a manual vacuum. Approximately $500 \mathrm{~mL}$ of rumen fluid was collected from at least 3 sites in the rumen (front, middle, and back) approximately $48 \mathrm{~cm}$ deep. The $\mathrm{pH}$ of the fluid was determined immediately, and then the rumen fluid was strained through 2 layers of cheesecloth. Two $40-\mathrm{mL}$ samples of strained fluid were added to $2.4 \mathrm{~mL}$ of $0.6 \mathrm{~N} \mathrm{HCl}$ and retained for analysis of ammonia and total free AA. A 1-mL sample of rumen fluid was added to $0.02 \mathrm{~mL}$ of $50 \% \mathrm{H}_{2} \mathrm{SO}_{4}$ and retained for VFA analysis. Samples retained for ammonia, AA, and VFA analysis were immediately frozen.

Ruminal particle-associated and fluid-associated bacteria were isolated from ruminal digesta at 0700, 1100, 1500 , and $1900 \mathrm{~h}$ on d 10 and at 0900,1230 , and 1700 $\mathrm{h}$ on $\mathrm{d} 12$. Isolation of bacteria followed the procedures of Whitehouse et al. (1994) and Putnam et al. (1997). Isolated bacteria were lyophilized, and fluid- and particle-associated bacteria were then combined.

Blood was collected by venipuncture of the coccygeal vein at $1500 \mathrm{~h}$ on $\mathrm{d} 9$ and 11 of each period. Blood was collected in 10-mL evacuated tubes (Vacutainer, Becton Dickinson, Rutherford, NJ) containing sodium heparin. Blood tubes were immediately placed into an ice bath and centrifuged (Centra, International Equipment
Company, Needham Heights, MA) within 45 min at $3,300 \times g$ for $20 \mathrm{~min}$ at $5^{\circ} \mathrm{C}$. An aliquot of plasma was deproteinized by vortexing (Vortex Genie, Scientific Industries Inc., Springfield, MA) 4 volumes of plasma with 1 volume of $15 \%$ sulfosalicylic acid; centrifugation followed at $3,300 \times g$ for $20 \mathrm{~min}$ at $5^{\circ} \mathrm{C}$. The supernatant was collected and equal aliquots were placed into Nunc Cyro Tube vials (Nalge Nunc International, Roskilde, Denmark) and stored at $-80^{\circ} \mathrm{C}$ until analyzed.

Milk samples were obtained from each cow during the a.m., noon, and p.m. milkings on $d 12$ and 13 of each period. Samples were preserved with 2-bromo-2nitropropane-1,3-diol (1 tablet per $40 \mathrm{~mL}$ of milk). Samples were refrigerated until they were composited daily by milk weights to reflect the proportion of the milk given at each milking.

\section{Analytical Procedures}

The lyophilized duodenal samples were ground to pass through a 1-mm screen using a Wiley mill for analysis of $\mathrm{ADF}, \mathrm{NDF}, \mathrm{CP}$, fat, ash, and starch done by Dairy One DHI Forage Testing Laboratory (Ithaca, NY). Duodenal digesta was analyzed in duplicate for $\mathrm{DM}$ at $100^{\circ} \mathrm{C}$ for $6 \mathrm{~h}$ in a vacuum oven (National Appliance Co., Portland, OR). A subportion of the ground duodenal digesta was further ground to pass through a 40- $\mu \mathrm{m}$ screen (Arthur H. Thomas Co., Philadelphia, PA) for purine and AA analyses. Lyophilized, isolated rumen bacteria were also ground to pass through a 1- 
Table 4. Effect of urea supplementation on ruminal digestibility and fermentation

\begin{tabular}{|c|c|c|c|c|c|c|c|}
\hline \multirow[b]{2}{*}{ Item } & \multicolumn{4}{|c|}{ Treatment (\% urea, DM basis) } & \multirow[b]{2}{*}{$\mathrm{SE}^{1}$} & \multicolumn{2}{|c|}{ Contrast ( $P$-value $)$} \\
\hline & 0.0 & 0.3 & 0.6 & 0.9 & & Linear & Quadratic \\
\hline \multicolumn{8}{|l|}{ Ruminal digestibility } \\
\hline \multicolumn{8}{|l|}{ DM } \\
\hline Intake, kg/d & 20.6 & 19.9 & 21.1 & 21.4 & 0.83 & NS & NS \\
\hline Flow, kg/d & 15.7 & 16.0 & 15.7 & 15.9 & 1.21 & NS & NS \\
\hline True digestibility, $\%$ & 37.8 & 38.7 & 39.5 & 37.3 & 6.01 & NS & NS \\
\hline \multicolumn{8}{|l|}{$\mathrm{OM}$} \\
\hline Intake, kg/d & 18.9 & 18.3 & 19.3 & 19.8 & 0.75 & NS & NS \\
\hline Flow, kg/d & 12.0 & 12.6 & 12.1 & 12.1 & 0.77 & NS & NS \\
\hline True digestibility, \% & 50.4 & 45.1 & 51.8 & 50.6 & 4.44 & NS & NS \\
\hline \multicolumn{8}{|l|}{ Starch } \\
\hline Intake, kg/d & 5.1 & 4.9 & 5.2 & 5.2 & 0.20 & NS & NS \\
\hline True digestibility, \% & 74.6 & 69.8 & 67.8 & 64.0 & 5.94 & NS & NS \\
\hline \multicolumn{8}{|l|}{$\mathrm{CHO}^{2}$} \\
\hline Intake, kg/d & 15.0 & 14.6 & 14.7 & 15.0 & 0.58 & NS & NS \\
\hline True digestibility, $\%$ & 67.0 & 63.5 & 65.5 & 63.8 & 2.88 & NS & NS \\
\hline \multicolumn{8}{|l|}{$\mathrm{ADF}$} \\
\hline Intake, kg/d & 4.6 & 4.5 & 4.7 & 4.7 & 0.18 & NS & NS \\
\hline Apparent digestibility, \% & 25.9 & 24.7 & 30.6 & 30.3 & 5.48 & NS & NS \\
\hline \multicolumn{8}{|l|}{ NDF } \\
\hline Intake, kg/d & 7.4 & 7.1 & 7.5 & 7.6 & 0.30 & NS & NS \\
\hline Apparent digestibility, $\%$ & 34.2 & 35.7 & 35.7 & 38.9 & 4.40 & NS & NS \\
\hline \multicolumn{8}{|l|}{ Ruminal fermentation } \\
\hline $\mathrm{pH}$ & 6.19 & 6.21 & 6.20 & 6.25 & 0.07 & NS & NS \\
\hline Ammonia $\mathrm{N}, \mathrm{mg} / \mathrm{dL}$ & $9.0^{\mathrm{a}}$ & $11.9^{\mathrm{a}}$ & $12.8^{\mathrm{a}}$ & $17.4^{\mathrm{b}}$ & 1.40 & $<0.001$ & $<0.01$ \\
\hline TFAA, ${ }^{3} \mathrm{~m} M$ & 3.3 & 3.1 & 3.1 & 3.1 & 0.19 & NS & NS \\
\hline Total VFA, ${ }^{4} \mathrm{mmol} / \mathrm{L}$ & $104.8^{\mathrm{a}}$ & $107.6^{\mathrm{a}}$ & $107.4^{\mathrm{a}}$ & $113.4^{\mathrm{b}}$ & 2.62 & 0.01 & NS \\
\hline \multicolumn{8}{|l|}{ Individual VFA, mol/100 mol } \\
\hline Acetate & 63.1 & 63.6 & 63.3 & 63.8 & 0.42 & NS & NS \\
\hline Propionate & 18.6 & 18.3 & 18.6 & 18.1 & 0.73 & NS & NS \\
\hline Butyrate & 11.3 & 11.2 & 11.0 & 11.3 & 0.62 & NS & NS \\
\hline
\end{tabular}

${ }^{\mathrm{a}, \mathrm{b}}$ Least squares means within the same row without a common superscript $\operatorname{differ}(P<0.05)$.

${ }^{1} \mathrm{SE}=$ standard error for $\mathrm{n}=4 ; \mathrm{n}=3$ for $0.3 \%$ urea treatment.

${ }^{2} \mathrm{CHO}=$ carbohydrate $(\mathrm{OM}-\mathrm{CP}-$ crude fat $)$.

${ }^{3} \mathrm{TFAA}=$ total free AA in the composited rumen fluid samples.

${ }^{4}$ Total VFA includes acetate, propionate, butyrate, isobutyrate, valerate, and isovalerate.

mm screen using a Wiley mill. This portion of the bacteria was used for fat, $\mathrm{CP}$, and ash analysis. A subportion of the rumen bacteria was further ground to pass through a $40-\mu \mathrm{m}$ screen for purine analysis.

A portion of the duodenal sample that was ground through a 1-mm screen was used for $\mathrm{Cr}$ analysis via inductively coupled plasma optical emission spectrophotometry (Varian Instrument, Walnut Creek, CA) using the method reported by Williams et al. (1962). Briefly, $0.5 \mathrm{~g}$ of duodenal sample was ashed at $500^{\circ} \mathrm{C}$ for $4 \mathrm{~h}$. Samples were cooled at room temperature $\left(23^{\circ} \mathrm{C}\right)$ and then were digested with a phosphoric acidmanganese sulphate solution and potassium bromate. A recovery test was also used to determine the accuracy of the procedure. Twenty milligrams of $\mathrm{Cr}_{2} \mathrm{O}_{3}$ was added to and thoroughly mixed with $3.98 \mathrm{~g}$ of dried, ground duodenal sample from a cow that was not dosed with $\mathrm{Cr}_{2} \mathrm{O}_{3}$. One-half of a gram of this sample was then ashed and digested as described above. Recovery of the $\mathrm{Cr}$ from this sample averaged $94 \%$.
Analysis of duodenal digesta and rumen bacteria samples for purines was conducted using the method of Makkar and Becker (1999), with some modifications. The amount of sample weighed out for analysis was $0.350 \mathrm{~g}$ for duodenal digesta and $0.125 \mathrm{~g}$ for rumen bacteria. Also, the time of the first centrifugation step was increased from 10 to 30 min to ensure complete capture of purines in the pellet. The proportion of the duodenal total $\mathrm{N}$ that was of bacterial origin was calculated by dividing the $\mathrm{N}$ to purine ratio of the mixed rumen bacterial cells by the $\mathrm{N}$ to purine ratio of duodenal digesta.

Frozen samples of ruminal and duodenal fluid were allowed to thaw at room temperature and then analyzed for ammonia concentration (407A Specific Ion Meter, Orion, Boston, MA) according to the method of Schwab et al. (1992). Thawed rumen fluid was analyzed for VFA concentrations via gas chromatography following the procedure of Yang and Varga (1989). Analysis of rumen fluid for total free AA was conducted on composite sam- 
ples for each cow from each period. Two milliliters of rumen fluid from each collected sample was used to make up the composites. Total free AA were determined using a fluorimetric procedure based on reaction with $o$-phthalaldehyde (Roth, 1971). Leucine was used as the standard in the $o$-phthalaldehyde assay. Total free AA are reported in leucine equivalents.

Plasma and lyophilized duodenal digesta (ground to pass a $40-\mu \mathrm{m}$ screen) were analyzed for AA concentrations via ion-exchange chromatography (AOAC, 2000, Experimental Station Chemical Laboratories, University of Missouri-Columbia, Columbia). Milk samples were analyzed for true protein, fat, and urea by midinfrared spectrophotometric analysis with a Foss 4000 (Dairy One, Northeast DHIA Laboratory).

\section{In Situ Procedure and Analysis}

Due to practical limitations of rumen size and the limited number of days available for ruminal incubation studies, only corn silage, ground corn, and SBM were evaluated. These feedstuffs were selected for incubation because they represented the primary forage, energy concentrate, and protein supplement in the diets. The in situ method used followed the procedures of Lykos and Varga (1995). The corn silage samples were dried at $55^{\circ} \mathrm{C}$ in a forced-air oven and concentrate ingredients were air-dried. All dried samples were ground to pass a 2-mm screen using a Wiley mill. Polyester bags (Ankom Technologies, Macedon, NY) with a mean pore size of $50 \mu \mathrm{m}$ and dimensions of $10 \times 20 \mathrm{~cm}$ were used. Approximately $7.4 \mathrm{~g}$ of sample was weighed into the bag, and the bags were tied with plastic fastening ties $2 \mathrm{~cm}$ below the top of the bag. All samples were incubated in duplicate for the first $24 \mathrm{~h}$, and after this time, 4 bags per sample were incubated for each time point. The bags were incubated in the rumen for $0,2,4,8,12,16,24$, 36 , and $48 \mathrm{~h}$. Bags were inserted in reverse order and retrieved at $0 \mathrm{~h}$. The first set of bags were placed in the rumen after the last rumen sample was collected on $\mathrm{d} 12$ and all bags were removed from the rumen on d 14 of each period.

\section{Calculations and Statistical Analysis}

Apparent and true digestibility of nutrients in the rumen were calculated as follows (using $\mathrm{OM}$ as an example):

Apparent ruminal OM digestibility =

[(OM intake - duodenal OM flow $) / O M$ intake $] \times 100$

True ruminal $\mathrm{OM}$ digestibility =

[(OM intake - (duodenal OM flow -

duodenal bacteria OM flow)/OM intake] $\times 100$.
Fractional degradation rates and effective ruminal degradabilities (ED) of DM, CP, and NDF in the rumen were calculated using the nonlinear model of Ørskov and McDonald (1979). The PROC NLIN procedure of SAS (SAS Institute, 2001) was used to fit a lag and a nonlag model in the degradation curves of the different feedstuffs. For the nonlag model, the equation was the following

$$
\mathrm{P}=\mathrm{A}+\mathrm{B}\left(1-\mathrm{e}^{-\mathrm{ct}}\right)
$$

where $\mathrm{P}$ is disappearance (\%), $\mathrm{A}$ is the soluble fraction $(\%), \mathrm{B}$ is the potentially degradable fraction $(\%), \mathrm{c}$ is the fractional degradation rate $(\% / \mathrm{h})$, and $\mathrm{t}$ is time $(\mathrm{h})$.

For the lag model, the equation was

$$
\mathrm{P}=\mathrm{A}+\mathrm{B}\left(1-\mathrm{e}^{-(\mathrm{t}-\mathrm{L}) \mathrm{c}}\right)
$$

when $\mathrm{L}<\mathrm{t}$ and $\mathrm{P}=\mathrm{A}$ when $\mathrm{L} \geq \mathrm{t}$, where $\mathrm{L}$ is lag time (h), and other terms are as defined previously.

Effective ruminal degradabilities of CP and DM (nonlag model) were calculated by

$$
\mathrm{ED}=\mathrm{A}+\mathrm{B}[\mathrm{c} /(\mathrm{c}+\mathrm{k})]
$$

where $\mathrm{k}$ is fractional passage rate (assumed to be $6 \% /$ h). Effective ruminal degradabilities of NDF (lag model) were calculated by

$$
\mathrm{ED}=\mathrm{A}+\mathrm{B}[\mathrm{c} /(\mathrm{c}+\mathrm{k})]\left(1-\mathrm{e}^{-(\mathrm{c}+\mathrm{k})(\mathrm{t}-\mathrm{L})}\left(\mathrm{e}^{-{ }^{\mathrm{kL}}}\right) .\right.
$$

Both models were analyzed with and without the constraint $\mathrm{A}+\mathrm{B} \leq 100$.

The data from the cow that was removed from the experiment in period 1 was not used in the final statistical analysis. Data from the cow assigned to the study at the beginning of period 2 were used for the final statistical analysis, with period 1 treated as missing data. All intake, duodenal flow, digestibility, in situ, and production-related data were reduced to cow-period means before statistical analysis $(n=15)$. Data were analyzed as a Latin square design according to the following model:

$$
\mathrm{Y}_{\mathrm{ijk}}=\mu+\mathrm{U}_{\mathrm{i}}+\mathrm{P}_{\mathrm{j}}+\mathrm{c}(\mathrm{U})_{\mathrm{ik}}+\mathrm{E}_{\mathrm{ijk}}
$$

where $Y_{i j k}=$ the dependent variable, $\mu$ = overall mean, $\mathrm{U}_{\mathrm{i}}=$ the fixed effect of the ith treatment level of urea, $\mathrm{i}=1, \ldots 4, \mathrm{P}_{\mathrm{j}}=$ the random effect of the jth period, $\mathrm{j}=$ $1, \ldots 4, \mathrm{c}(\mathrm{U})_{\mathrm{ik}}=$ the random effect of the kth cow with the ith level of urea, $\mathrm{l}=1, \ldots 0.4$, and $\mathrm{E}_{\mathrm{ijk}}=$ the random residual $\sim \mathrm{N}\left(0, \sigma^{2}{ }_{\mathrm{e}}\right)$. 


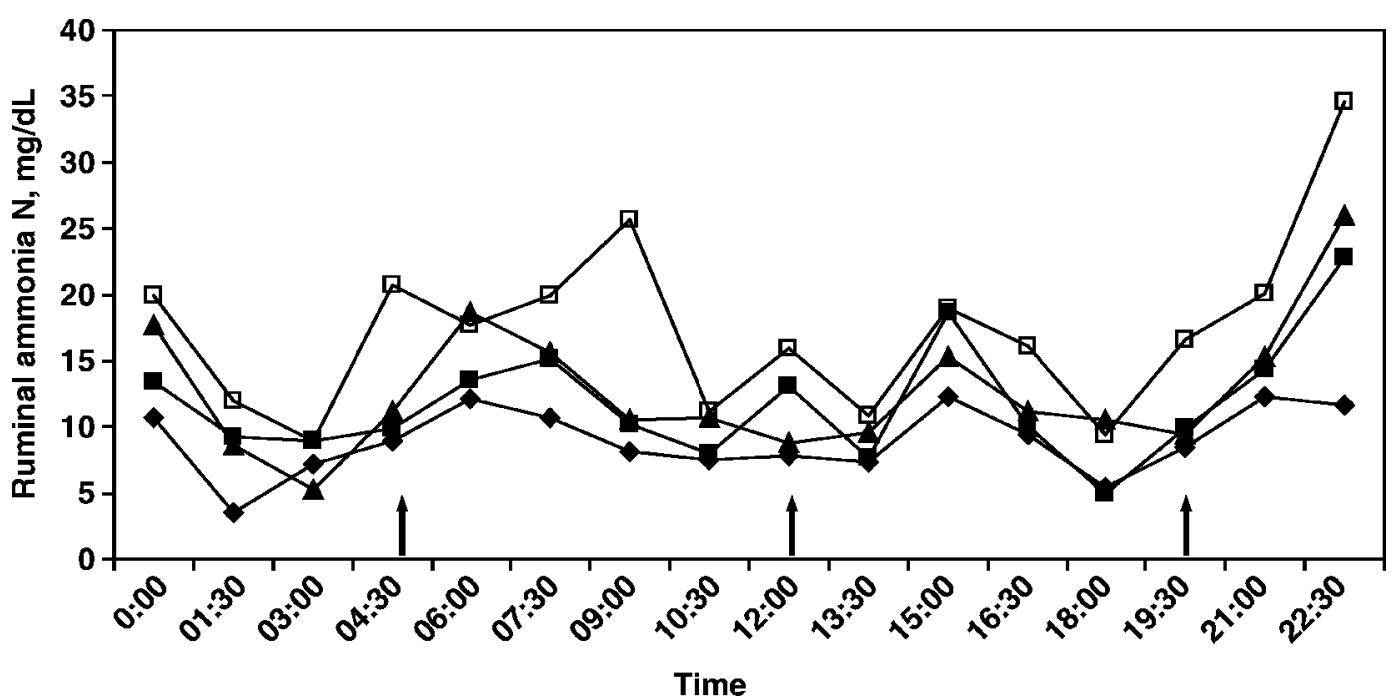

Figure 1. Ammonia N concentrations of rumen fluid of Holstein dairy cows fed diets containing $0(\bullet), 0.3(\boldsymbol{\square}), 0.6(\boldsymbol{\Delta})$, or $0.9 \%(\square)$ urea in diet DM over $24 \mathrm{~h}$. Significant effect of time $(P<0.001$; SEM $=2.04)$ was observed. Arrows indicate time of feeding.

The following model was used for ruminal variables for which there were repeated measurements over time ( $\mathrm{pH}$, ammonia $\mathrm{N}$, and VFA):

$$
\mathrm{Y}_{\mathrm{ijkl}}=\mu+\mathrm{U}_{\mathrm{i}}+\mathrm{P}_{\mathrm{j}}+\mathrm{c}(\mathrm{U})_{\mathrm{ik}}+\mathrm{T}_{\mathrm{l}}+\mathrm{UT}_{\mathrm{il}},+\mathrm{C}_{\mathrm{ijkl}}+\mathrm{E}_{\mathrm{ijkl}}
$$

where $Y_{\mathrm{ijkl}}=$ the dependent variable, $\mu$ = overall mean, $U_{i}=$ the fixed effect of the ith level of urea, $i=1, \ldots 4$, $P_{j}=$ the random effect of the $j$ th period, $j=1, \ldots 4$, $\mathrm{c}(\mathrm{U})_{\mathrm{ik}}=$ the random effect of the kth cow with the ith treatment level of urea, $\mathrm{k}=1 \ldots 4, \mathrm{~T}_{1}=$ effect of time, $\mathrm{l}=1 \ldots 16, \mathrm{UT}_{\mathrm{il}}=$ interaction between level of urea $\mathrm{i}$ and effect of time $1, \mathrm{C}_{\mathrm{ijkl}}=$ the value of the covariate variable for the kth cow of the ith level of urea of the $\mathrm{jth}$ period of the lth time, and $\mathrm{E}_{\mathrm{ijkl}}=$ the random residual $\sim \mathrm{N}\left(0, \sigma^{2}{ }_{\mathrm{e}}\right)$. Data were run through 3 covariance structures: unstructured, compound symmetry, and first-order autoregressive. Compound symmetry was the covariance structure used because it resulted in the best fit according to Sawa's Bayesian information criterion.

The MIXED procedure of SAS (SAS Institute, 2001) was used to solve the above models. Linear, quadratic, and cubic contrasts were fitted within each treatment, and the PDIFF statement in SAS was used to determine differences between treatments. Results are expressed as least squares means with the lowest standard error. Significance was declared at $P<0.05$ and tendencies were reported at $0.05<P<0.10$.

\section{RESULTS}

The NRC (2001) evaluation of the consumed diets is presented in Table 2, and the chemical composition of the feeds is listed in Table 3 . The RDP balance of the $0,0.3,0.6$, and $0.9 \%$ urea diets was $92,100,109$, and $117 \%$ of NRC (2001) predicted requirements (Table 2). The average amounts of urea that were fed for the 0 , $0.3,0.6$, and $0.9 \%$ urea diets were $0,63,127$, and 192 $\mathrm{g} / \mathrm{d}$, respectively. The average particle size distribution for the TMR using the Penn State Particle Separator for the top, middle, and bottom screens were (mean \pm SD) $21 \pm 10,35 \pm 6$, and $44 \pm 4 \%$, respectively. The orts averaged (mean \pm SD) $16 \pm 9 \%$ of feed offered, and the particle size distribution of the orts for the top, middle, and bottom screens averaged (mean \pm SD) $24 \pm 11,40$ \pm 6 , and $36 \pm 6 \%$, respectively. Orts were similar to the TMR in distribution on the screens thus indicating that the animals did not sort the diet.

There was no effect of treatment on intake or ruminal digestibility of diet DM, OM, starch, and carbohydrate (CHO; $\mathrm{CHO}=\mathrm{OM}$ - CP - crude fat), $\mathrm{ADF}$, or NDF (Table 4). Ruminal ammonia $\mathrm{N}$ concentrations increased quadratically with increasing urea supplementation: $9.0,11.9,12.8$, and $17.4 \mathrm{mg} / \mathrm{dL}$ for the $0,0.3$, 0.6 , and $0.9 \%$ urea diets, respectively. There was no effect of urea treatment on ruminal $\mathrm{pH}$ or total free AA concentrations in rumen fluid. Ruminal concentrations of total VFA increased linearly with increasing urea supplementation. However, only the $0.9 \%$ urea diet was significantly different from the other 3 treatments. There was no effect of urea supplementation on the molar proportions of acetate, propionate, or butyrate. There was no significant treatment $\times$ time interaction for ruminal ammonia $\mathrm{N}$ concentrations, ruminal VFA concentrations, molar proportion of VFA, and ruminal $\mathrm{pH}$ (data not presented). Ruminal ammonia N concen- 
Table 5. Effect of urea supplementation on in situ degradability of corn silage, ground corn, and soybean meal

\begin{tabular}{|c|c|c|c|c|c|c|c|}
\hline \multirow[b]{2}{*}{ Item } & \multicolumn{4}{|c|}{ Treatment (\% urea, DM basis) } & \multirow[b]{2}{*}{$\mathrm{SE}^{1}$} & \multicolumn{2}{|c|}{ Contrast ( $P$-value $)$} \\
\hline & 0.0 & 0.3 & 0.6 & 0.9 & & Linear & Quadratic \\
\hline \multicolumn{8}{|l|}{ Corn silage } \\
\hline \multicolumn{8}{|l|}{$\mathrm{DM}$} \\
\hline $\mathrm{A}, \%$ & 43.8 & 44.1 & 44.0 & 43.6 & 1.53 & NS & NS \\
\hline B, \% & 54.6 & 44.5 & 45.0 & 51.3 & 4.85 & NS & NS \\
\hline Rate, $\% / \mathrm{h}$ & 1.7 & 2.6 & 2.4 & 2.0 & 0.44 & NS & NS \\
\hline $\mathrm{EDDM}^{2}$ & 55.9 & 55.3 & 56.2 & 56.0 & 1.08 & NS & NS \\
\hline \multicolumn{8}{|l|}{$\mathrm{CP}$} \\
\hline A, \% & 65.1 & 63.3 & 65.6 & 64.1 & 1.93 & NS & NS \\
\hline $\mathrm{B}, \%$ & $22.7^{\mathrm{a}}$ & $21.3^{\mathrm{a}}$ & $23.2^{\mathrm{a}}$ & $30.4^{\mathrm{b}}$ & 2.66 & 0.02 & 0.05 \\
\hline Rate, $\% / \mathrm{h}$ & 4.0 & 5.0 & 4.5 & 2.5 & 0.97 & NS & NS \\
\hline $\mathrm{EDCP}^{2}$ & 73.1 & 73.0 & 73.9 & 72.5 & 1.56 & NS & NS \\
\hline \multicolumn{8}{|l|}{$\mathrm{NDF}$} \\
\hline A, \% & 14.7 & 14.8 & 14.0 & 15.2 & 1.70 & NS & NS \\
\hline $\mathrm{B}, \%$ & 85.3 & 85.2 & 86.0 & 84.8 & 1.70 & NS & NS \\
\hline Rate, $\% / \mathrm{h}$ & 1.0 & 1.1 & 1.2 & 1.0 & 0.09 & NS & NS \\
\hline Lag, h & 0.4 & 1.0 & 0.3 & 0.5 & 0.18 & NS & NS \\
\hline $\mathrm{EDNDF}^{2}$ & 26.7 & 27.3 & 27.3 & 26.8 & 1.63 & NS & NS \\
\hline \multicolumn{8}{|l|}{ Corn } \\
\hline \multicolumn{8}{|l|}{ DM } \\
\hline A, \% & 31.5 & 31.4 & 33.5 & 31.8 & 1.61 & NS & NS \\
\hline $\mathrm{B}, \%$ & 69.0 & 62.7 & 67.6 & 68.3 & 2.85 & NS & NS \\
\hline Rate, $\% / \mathrm{h}$ & 5.8 & 7.0 & 5.9 & 5.8 & 1.04 & NS & NS \\
\hline $\mathrm{EDDM}^{2}$ & 65.0 & 65.2 & 65.6 & 64.7 & 2.65 & NS & NS \\
\hline $\mathrm{CP}$ & & & & & & NS & NS \\
\hline A, \% & 23.8 & 27.3 & 25.9 & 24.0 & 2.15 & NS & NS \\
\hline $\mathrm{B}, \%$ & 73.0 & 72.8 & 73.4 & 76.0 & 3.05 & NS & NS \\
\hline Rate, $\% / \mathrm{h}$ & 7.7 & 7.3 & 7.2 & 7.2 & 0.93 & NS & NS \\
\hline $\mathrm{EDCP}^{2}$ & 64.1 & 66.0 & 65.2 & 64.9 & 2.85 & NS & NS \\
\hline \multirow{2}{*}{\multicolumn{8}{|c|}{ Soybean meal }} \\
\hline \multicolumn{5}{|l|}{ DM } & & & \\
\hline $\mathrm{A}, \%$ & 38.9 & 40.3 & 40.3 & 39.3 & 1.57 & NS & NS \\
\hline B, \% & 64.4 & 63.2 & 61.3 & 64.3 & 2.16 & NS & NS \\
\hline Rate, $\% / \mathrm{h}$ & 7.4 & 7.3 & 8.2 & 7.3 & 0.83 & NS & NS \\
\hline $\mathrm{EDDM}^{2}$ & 73.8 & 74.7 & 75.6 & 74.1 & 1.52 & NS & NS \\
\hline \multicolumn{8}{|l|}{$\mathrm{CP}$} \\
\hline A, \% & 23.8 & 27.3 & 25.9 & 24.0 & 2.15 & NS & NS \\
\hline $\mathrm{B}, \%$ & 73.0 & 72.8 & 73.4 & 76.0 & 3.05 & NS & NS \\
\hline Rate, $\% / \mathrm{h}$ & 7.7 & 7.3 & 7.2 & 7.2 & 0.93 & NS & NS \\
\hline $\mathrm{EDCP}^{2}$ & 64.1 & 66.0 & 65.2 & 64.9 & 2.85 & NS & NS \\
\hline
\end{tabular}

${ }^{\mathrm{a}, \mathrm{b}}$ Least squares means within the same row without a common superscript $\operatorname{differ}(P<0.05)$.

${ }^{1} \mathrm{SE}=$ standard error for $\mathrm{n}=4 ; \mathrm{n}=3$ for $0.3 \%$ urea treatment.

${ }^{2}$ Effective degradability of DM, CP, or NDF at assumed passage rate (kp) of $6 \%$.

trations generally increased right after feeding (Figure 1).

There was no effect of treatment on in situ determined degradability coefficients and ED for DM and CP for corn silage, ground corn, or SBM, and there was also no effect of treatment on in situ degradability coefficients and ED for NDF for corn silage (Table 5). Increasing levels of urea supplementation also had no effect on the rate of digestion of these feedstuffs. The potentially degradable CP fraction (B) of corn silage increased quadratically with increasing urea supplementation: $22.7,21.3,23.2$, and $30.4 \%$ for the $0,0.3$, 0.6 , and $0.9 \%$ urea diets, respectively.

Flow of ammonia $\mathrm{N}$ to the duodenum increased linearly with increasing urea supplementation (Table 6).
There was a quadratic effect of treatment on microbial $\mathrm{N}$ flow to the duodenum and microbial $\mathrm{N}$ as a percentage of NAN. Flow of microbial $\mathrm{N}$ to the duodenum and microbial $\mathrm{N}$ expressed as a percentage of NAN were maximized with $0.6 \%$ urea supplementation and were $283 \mathrm{~g} / \mathrm{d}$ and $49.4 \%$, respectively. Flows of total $\mathrm{N}$ and nonammonia nonmicrobial N (NANMN, g/d) were not affected by increasing urea supplementation. However, there was a quadratic effect of treatment on NANMN as a percentage of NAN, and the lowest value for this measurement $(50.6 \%)$ was observed with $0.6 \%$ urea supplementation. A quadratic trend $(P=0.06)$ for the efficiency of microbial protein synthesis expressed as grams of microbial N/kilogram of OM truly digested (OMTD) was observed. The largest value for this mea- 
Table 6. Effect of urea supplementation on intake, flow to the duodenum, and ruminal digestibility of $\mathrm{N}$

\begin{tabular}{|c|c|c|c|c|c|c|c|}
\hline \multirow[b]{2}{*}{ Item $^{1}$} & \multicolumn{4}{|c|}{ Treatment (\% urea, DM basis) } & \multirow[b]{2}{*}{$\mathrm{SE}^{2}$} & \multicolumn{2}{|c|}{ Contrast ( $P$-value) } \\
\hline & 0.0 & 0.3 & 0.6 & 0.9 & & Linear & Quadratic \\
\hline $\mathrm{N}$ intake, $\mathrm{g} / \mathrm{d}$ & $491^{\mathrm{a}}$ & $501^{\mathrm{a}}$ & $556^{\mathrm{b}}$ & $594^{\mathrm{b}}$ & 20.8 & $<0.01$ & NS \\
\hline $\begin{array}{l}\text { Flow to the duodenum, g/d } \\
\text { Total N } \\
\text { Ammonia N } \\
\text { NAN } \\
\text { Microbial N (MN) } \\
\text { NANMN }\end{array}$ & $\begin{array}{l}624 \\
17^{\mathrm{a}} \\
607 \\
243^{\mathrm{ab}} \\
364\end{array}$ & $\begin{array}{l}628 \\
17^{\mathrm{a}} \\
611 \\
272^{\mathrm{bc}} \\
337\end{array}$ & $\begin{array}{c}604 \\
20^{\mathrm{ab}} \\
584 \\
283^{\mathrm{c}} \\
301\end{array}$ & $\begin{array}{c}598 \\
24^{\mathrm{b}} \\
574 \\
224^{\mathrm{a}} \\
350\end{array}$ & $\begin{array}{r}45.6 \\
1.8 \\
45.0 \\
11.4 \\
43.0\end{array}$ & $\begin{array}{c}\text { NS } \\
<0.01 \\
\text { NS } \\
\text { NS } \\
\text { NS }\end{array}$ & $\begin{array}{c}\text { NS } \\
\text { NS } \\
\text { NS } \\
0.01 \\
\text { NS }\end{array}$ \\
\hline $\begin{array}{l}\text { Flow to the duodenum, } \% \text { of NAN } \\
\text { MN } \\
\text { NANMN }\end{array}$ & $\begin{array}{l}40.6^{\mathrm{a}} \\
59.4^{\mathrm{b}}\end{array}$ & $\begin{array}{l}45.6^{\mathrm{ab}} \\
54.4^{\mathrm{ab}}\end{array}$ & $\begin{array}{l}49.4^{\mathrm{b}} \\
50.6^{\mathrm{a}}\end{array}$ & $\begin{array}{l}39.3^{\mathrm{a}} \\
60.7^{\mathrm{b}}\end{array}$ & $\begin{array}{l}3.45 \\
3.47\end{array}$ & $\begin{array}{l}\text { NS } \\
\text { NS }\end{array}$ & $\begin{array}{l}0.03 \\
0.03\end{array}$ \\
\hline $\begin{array}{l}\text { Efficiency of microbial protein synthesis, } \\
\mathrm{g} \text { of microbial N/kg of OMTD } \\
\mathrm{g} \text { of microbial N/kg of CHOTD } \\
\mathrm{g} \text { of microbial N/kg of DMI } \\
\mathrm{g} \text { of microbial N/g of N intake } \\
\mathrm{g} \text { of microbial N/g of RDP-N }\end{array}$ & $\begin{array}{l}26.0^{\mathrm{ab}} \\
27.2 \\
11.9^{\mathrm{ab}} \\
0.50^{\mathrm{b}} \\
0.81^{\mathrm{b}}\end{array}$ & $\begin{array}{l}36.2^{\mathrm{b}} \\
34.3^{\mathrm{b}} \\
13.7^{\mathrm{b}} \\
0.55^{\mathrm{b}} \\
0.85^{\mathrm{b}}\end{array}$ & $\begin{array}{l}29.9^{\mathrm{ab}} \\
33.4 \\
13.5^{\mathrm{b}} \\
0.51^{\mathrm{b}} \\
0.77^{\mathrm{b}}\end{array}$ & $\begin{array}{l}22.4^{\mathrm{a}} \\
25.6 \\
10.4^{\mathrm{a}} \\
0.38^{\mathrm{a}} \\
0.56^{\mathrm{a}}\end{array}$ & $\begin{array}{l}3.47 \\
2.53 \\
0.67 \\
0.027 \\
0.438\end{array}$ & $\begin{array}{c}\mathrm{NS} \\
\mathrm{NS} \\
\mathrm{NS} \\
0.02 \\
<0.01\end{array}$ & $\begin{array}{l}0.06 \\
0.03 \\
0.02 \\
0.02 \\
0.04\end{array}$ \\
\hline $\begin{array}{l}\mathrm{N} \text { truly digested, } \\
\mathrm{g} / \mathrm{d} \\
\% \text { of intake }\end{array}$ & $\begin{array}{r}127^{\mathrm{a}} \\
26.5\end{array}$ & $\begin{array}{c}160^{\mathrm{a}} \\
30.4\end{array}$ & $\begin{array}{c}255^{\mathrm{b}} \\
45.2\end{array}$ & $\begin{array}{c}244^{\mathrm{b}} \\
41.1\end{array}$ & $\begin{array}{r}47.0 \\
8.2\end{array}$ & $\begin{array}{l}0.04 \\
0.09\end{array}$ & $\begin{array}{l}\text { NS } \\
\text { NS }\end{array}$ \\
\hline
\end{tabular}

${ }^{\mathrm{a}-\mathrm{c}}$ Least squares means within the same row without a common superscript $\operatorname{differ}(P<0.05)$.

${ }^{1} \mathrm{NANMN}=$ nonammonia nonmicrobial N; OMTD = OM truly digested in the rumen; CHOTD = carbohydrate truly digested in the rumen.

${ }^{2} \mathrm{SE}=$ standard error for $\mathrm{n}=4 ; \mathrm{n}=3$ for $0.3 \%$ urea treatment.

surement was observed with $0.3 \%$ urea supplementation (36.2 g/kg of OMTD) followed by $0.6 \%$ urea supplementation ( $29.9 \mathrm{~g} / \mathrm{kg}$ of OMTD). Efficiency of microbial protein synthesis expressed as grams of microbial N/ kilogram of CHO truly digested (CHOTD) and grams of microbial-N/gram of RDP-N had quadratic effects with their maximum responses at $0.3 \%$ urea.

There was a quadratic effect of urea treatment on plasma total free AA concentrations: 224.4, 213.3, 202.8 , and $230.1 \mu \mathrm{g} / \mathrm{dL}$, for $0,0.3,0.6$, and $0.9 \%$ urea diets, respectively (Table 7). Similar quadratic responses were observed for plasma concentrations of lysine, threonine, asparagine, citrulline, proline, taurine, total nonessential AA, and total sulfur AA. There was also a trend for a quadratic effect of urea treatment on plasma arginine, aspartic acid, and glutamine concentrations $(P=0.10,0.08$, and 0.06 , respectively).

Milk yield, milk fat concentration and yield, milk true protein yield, and the efficiency of conversion of feed to milk were not affected by urea supplementation (Table 8). However, milk true protein concentration decreased linearly and MUN increased linearly with increasing urea supplementation. Milk protein $\mathrm{N}$ to feed $\mathrm{N}$ ratios decreased linearly with increasing urea supplementation.

\section{DISCUSSION}

\section{Dietary Treatments}

The basal diet was formulated to be deficient enough in RDP (Table 2) that ruminal ammonia $\mathrm{N}$ concentra- tions would be less than optimal and the concentration of ammonia $\mathrm{N}$ required for maximal synthesis of microbial protein and ruminal OM digestion could be determined. The upper limit of $0.9 \%$ dietary urea was chosen with the expectation that a maximum response could be observed. As the results indicated, both conditions were met. Urea toxicity was not a concern because of the amount of readily fermentable carbohydrates in the basal diet (41.6\% NFC; Table 2) and because inclusion rates of 1 to $2 \%$ urea in diet DM have been used in high-grain diets without adverse effects (Poos et al., 1979). Indeed, no signs of urea toxicity were observed in any of the animals in the study.

\section{Optimum Ruminal Ammonia N Concentrations}

The optimum ruminal ammonia $\mathrm{N}$ concentration has been defined as the minimum concentration of ammonia $\mathrm{N}$ necessary to support maximum synthesis of microbial protein (Satter and Slyter, 1974) and maximum ruminal degradability of DM (Mehrez et al., 1977). In the current experiment, urea was added to the diet at the levels described to determine the optimum ruminal ammonia $\mathrm{N}$ concentration for maximum flow of microbial protein to the duodenum, ruminal digestibility of diet OM, and ruminal degradability of the primary forage, energy, and protein feeds in the diet. To determine the optimum ruminal ammonia $\mathrm{N}$ concentration for maximum synthesis of microbial protein, maximum ruminal fermentation, or both, concentrations of ammo- 
BOUCHER ET AL.

Table 7. Effect of urea supplementation on concentrations of plasma amino acids

\begin{tabular}{|c|c|c|c|c|c|c|c|}
\hline \multirow[b]{2}{*}{$\mathrm{AA}, \mu \mathrm{g} / \mathrm{mL}$} & \multicolumn{4}{|c|}{ Treatment (\% urea, DM basis) } & \multirow[b]{2}{*}{$\mathrm{SE}^{1}$} & \multicolumn{2}{|c|}{ Contrast ( $P$-value $)$} \\
\hline & 0.0 & 0.3 & 0.6 & 0.9 & & Linear & Quadratic \\
\hline Total AA & $224.4^{\mathrm{b}}$ & $213.3^{\mathrm{ab}}$ & $202.8^{\mathrm{a}}$ & $230.1^{\mathrm{b}}$ & 8.97 & NS & 0.03 \\
\hline Total essential AA & $106.0^{\mathrm{ab}}$ & $103.7^{\mathrm{ab}}$ & $96.7^{\mathrm{a}}$ & $110.5^{\mathrm{b}}$ & 6.96 & NS & 0.08 \\
\hline Arginine & 9.95 & 9.19 & 9.06 & 9.97 & 0.60 & NS & 0.10 \\
\hline Histidine & 7.11 & 7.16 & 6.39 & 7.03 & 0.53 & NS & NS \\
\hline Isoleucine & 11.65 & 12.20 & 10.98 & 12.85 & 1.12 & NS & NS \\
\hline Leucine & 6.40 & 16.96 & 15.00 & 17.45 & 2.03 & NS & NS \\
\hline Lysine & $10.15^{\mathrm{ab}}$ & $9.10^{\mathrm{ab}}$ & $9.04^{\mathrm{a}}$ & $10.49^{\mathrm{b}}$ & 0.75 & NS & 0.03 \\
\hline Methionine & 3.68 & 3.49 & 3.28 & 3.44 & 0.32 & NS & NS \\
\hline Phenylalanine & 5.74 & 5.95 & 5.23 & 5.66 & 0.40 & NS & NS \\
\hline Threonine & $9.45^{\mathrm{ab}}$ & $8.47^{\mathrm{a}}$ & $8.71^{\mathrm{ab}}$ & $9.76^{\mathrm{b}}$ & 0.37 & NS & 0.03 \\
\hline Tryptophan & 5.49 & 5.18 & 4.79 & 5.79 & 0.43 & NS & NS \\
\hline Valine & 26.42 & 26.79 & 24.24 & 28.09 & 2.73 & NS & NS \\
\hline Total $\mathrm{BCAA}^{2}$ & 54.46 & 55.89 & 50.21 & 58.39 & 5.75 & NS & NS \\
\hline Total nonessential AA & $118.4^{\mathrm{bc}}$ & $108.9^{b}$ & $106.1^{\mathrm{a}}$ & $119.6^{\mathrm{c}}$ & 3.06 & NS & $<0.01$ \\
\hline Alanine & 18.93 & 17.16 & 16.81 & 16.93 & 1.13 & NS & NS \\
\hline Asparagine & $5.11^{\mathrm{b}}$ & $4.74^{\mathrm{ab}}$ & $4.49^{\mathrm{a}}$ & $5.18^{\mathrm{b}}$ & 0.27 & NS & $<0.01$ \\
\hline Aspartic acid & 0.13 & 0.10 & 0.08 & 0.12 & 0.02 & NS & 0.08 \\
\hline Citrulline & $10.59^{\mathrm{ab}}$ & $9.38^{\mathrm{ab}}$ & $9.35^{\mathrm{a}}$ & $11.34^{\mathrm{b}}$ & 1.14 & NS & 0.03 \\
\hline Cystine & 3.50 & 3.43 & 3.65 & 3.62 & 0.31 & NS & NS \\
\hline Glutamine & $26.33^{\mathrm{ab}}$ & $25.22^{\mathrm{ab}}$ & $24.63^{\mathrm{a}}$ & $28.68^{\mathrm{b}}$ & 1.60 & NS & 0.06 \\
\hline Glutamic acid & 6.22 & 5.96 & 5.51 & 6.17 & 0.53 & NS & NS \\
\hline Glycine & 17.54 & 16.67 & 15.27 & 18.54 & 2.61 & NS & NS \\
\hline Ornithine & 3.94 & 3.83 & 3.52 & 4.15 & 0.42 & NS & NS \\
\hline Proline & $7.36^{\mathrm{b}}$ & $6.95^{\mathrm{ab}}$ & $6.75^{\mathrm{a}}$ & $7.30^{\mathrm{ab}}$ & 0.32 & NS & 0.04 \\
\hline Serine & 6.68 & 6.13 & 5.98 & 6.20 & 0.25 & NS & NS \\
\hline Taurine & $4.62^{\mathrm{b}}$ & $3.85^{\mathrm{ab}}$ & $3.17^{\mathrm{a}}$ & $3.81^{\mathrm{ab}}$ & 0.62 & 0.03 & 0.03 \\
\hline Tyrosine & 3.50 & 3.43 & 3.65 & 3.62 & 0.31 & NS & NS \\
\hline Total sulfur AA & $12.61^{\mathrm{b}}$ & $11.51^{\mathrm{a}}$ & $10.89^{a}$ & $11.64^{\mathrm{a}}$ & 0.74 & 0.03 & 0.02 \\
\hline
\end{tabular}

${ }^{a-c}$ Least squares means within the same row without a common superscript $\operatorname{differ}(P<0.05)$.

${ }^{1} \mathrm{SE}=$ standard error for $\mathrm{n}=4 ; \mathrm{n}=3$ for $0.3 \%$ urea treatment.

${ }^{2} \mathrm{BCAA}=$ branched-chain amino acids.

nia $\mathrm{N}$ that limit, maximize, and stabilize or depress these parameters need to be observed. In addition, ruminal ammonia $\mathrm{N}$ concentrations reported in the literature to be adequate to support maximum degradability of DM are not always adequate to support maximum synthesis of microbial protein (Kang-Meznarich and Broderick, 1981). The optimum ruminal ammonia $\mathrm{N}$ concentrations reported vary between and within the parameters that are used to define the optimum concentrations (Hume et al., 1970; Odle and Schaeffer, 1987). In the present study, measurements of ruminal digestibility of diet OM; ED of corn silage, corn, and SBM; and microbial protein synthesis are discussed in relation to the urea supplementation levels that provide the mean ruminal ammonia $\mathrm{N}$ concentration required to optimize these parameters.

Table 8. Effect of urea supplementation on production

\begin{tabular}{|c|c|c|c|c|c|c|c|}
\hline \multirow[b]{2}{*}{ Item } & \multicolumn{4}{|c|}{ Treatment (\% urea, DM basis) } & \multirow[b]{2}{*}{$\mathrm{SE}^{1}$} & \multicolumn{2}{|c|}{ Contrast ( $P$-value) } \\
\hline & 0.0 & 0.3 & 0.6 & 0.9 & & Linear & Quadratic \\
\hline DM intake, $\mathrm{kg} / \mathrm{d}$ & 20.5 & 20.3 & 21.2 & 21.2 & 0.78 & NS & NS \\
\hline Milk yield, kg/d & 33.9 & 30.7 & 34.6 & 33.0 & 3.13 & NS & NS \\
\hline Milk yield/DMI, kg/kg & 1.68 & 1.52 & 1.65 & 1.57 & 0.16 & NS & NS \\
\hline Milk true protein, \% & $2.84^{\mathrm{a}}$ & $2.76^{\mathrm{b}}$ & $2.79^{\mathrm{ab}}$ & $2.77^{\mathrm{b}}$ & 0.12 & 0.049 & NS \\
\hline Milk fat, $\%$ & 3.11 & 3.06 & 3.17 & 3.14 & 0.19 & NS & NS \\
\hline Milk true protein, $\mathrm{g} / \mathrm{d}$ & 962 & 855 & 959 & 913 & 87.4 & NS & NS \\
\hline Milk fat, g/d & 1,048 & 951 & 1,083 & 1,043 & 94.6 & NS & NS \\
\hline Milk protein $\mathrm{N} /$ feed $\mathrm{N}$ intake, $\mathrm{g} / \mathrm{g}$ & $0.32^{\mathrm{c}}$ & $0.27^{\mathrm{ab}}$ & $0.28^{\mathrm{b}}$ & $0.25^{\mathrm{a}}$ & 0.03 & $<0.001$ & NS \\
\hline MUN, mg/dL & $11.0^{\mathrm{a}}$ & $11.0^{\mathrm{a}}$ & $12.5^{\mathrm{b}}$ & $13.2^{\mathrm{b}}$ & 1.53 & $<0.001$ & NS \\
\hline
\end{tabular}

${ }^{\mathrm{a}, \mathrm{b}}$ Least squares means within the same row without a common superscript $\operatorname{differ}(P<0.05)$.

${ }^{1} \mathrm{SE}=$ standard error for $\mathrm{n}=4 ; \mathrm{n}=3$ for $0.3 \%$ urea treatment. 


\section{Ruminal Digestibility}

Given that there was no effect of urea supplementation on ruminal digestibility of DM, OM, starch, CHO, $\mathrm{NDF}$, or ADF (Table 4), we could not determine the optimum ruminal ammonia $\mathrm{N}$ concentration required to maximize these measurements. However, the lowest mean concentration of ruminal ammonia $\mathrm{N}$ for the control diet $(9.0 \mathrm{mg} / \mathrm{dL})$ may have been adequate, or more than adequate, for maximum digestibility of diet OM. Kang-Meznarich and Broderick (1981) observed that a ruminal ammonia $\mathrm{N}$ concentration of $3.3 \mathrm{mg} / \mathrm{dL}$ was adequate to support maximum ruminal digestion of DM in nonlactating cows fed a pelleted diet (75\% corn, $19.5 \%$ cottonseed hulls, and $2.8 \%$ vitamins and minerals). The pellets were fed hourly and contained increasing levels of urea. Ruminal ammonia $\mathrm{N}$ concentrations were $1.3,3.3,8.5,13.8,22.8$, and $28.9 \mathrm{mg} / \mathrm{dL}$, and the respective ruminal DM digestibility values were 61,69 , 65, 69, 67, and 68\% (Kang-Meznarich and Broderick, 1981). Similarly, Balcells et al. (1993) observed little benefit on ruminal digestibility of $\mathrm{OM}$ when mean ruminal ammonia $\mathrm{N}$ concentrations were increased via continuous ruminal infusions of urea above $4.0 \mathrm{mg} / \mathrm{dL}$ in ewes fed a pelleted $\mathrm{NaOH}$-treated barley straw diet once daily. The OM digestibility coefficients were 38 , $43,44,45$, and 45 at ruminal ammonia $\mathrm{N}$ concentrations of $0.5,2.5,4.0,6.8$, and $10.6 \mathrm{mg} / \mathrm{dL}$.

Based on the results of Kang-Meznarich and Broderick (1981) and Balcells et al. (1993), it is possible that the ruminal ammonia $\mathrm{N}$ concentration required to maximize ruminal digestibility of $\mathrm{OM}$ in this experiment was lower than that of the lowest ruminal ammonia $\mathrm{N}$ concentration observed $(9.0 \mathrm{mg} / \mathrm{dL}$; Table 4$)$. Similar to this finding, Reynal and Broderick (2005) also did not observe an increase in ruminal digestibility of OM with increasing ruminal ammonia $\mathrm{N}$ concentrations. Reynal and Broderick (2005) observed ruminal OM true digestibility coefficients of $65,65,66$, and $65 \%$ when the mean ruminal ammonia $\mathrm{N}$ concentrations were $5.7,8.7,11.8$, and $12.3 \mathrm{mg} / \mathrm{dL}$, respectively. Reynal and Broderick (2005) fed lactating cows 50:50 forage:concentrate diets that varied in RDP and RUP concentrations. The RDP and RUP concentrations were altered by changing the amounts of solvent SBM, lignosulfonate-treated SBM, and urea in the diets. The lowest ruminal ammonia $\mathrm{N}$ concentrations reported by Reynal and Broderick (2005), and in the current experiment were greater than $4.0 \mathrm{mg} / \mathrm{dL}$. Therefore, it appears that ruminal ammonia $\mathrm{N}$ concentration was not a limiting factor of ruminal digestibility of $\mathrm{OM}$ in the diets fed in the aforementioned study, or in the present experiment.

The ruminal digestibility values calculated in the current experiment are based solely on the composition of the diet fed and were not adjusted for composition of orts. Orts were collected daily but were mistakenly discarded before being analyzed. Because intakes were not adjusted for composition of orts, the digestibility values may be affected slightly. However, we do not believe this error affected our ability to detect treatment effects on ruminal digestibility because we did not observe a difference in the appearance of the orts among cows, or among diets. There was a slightly greater percentage of orts on the top and middle screens of the particle separator than of the TMR, but this difference was small (21 and $35 \%$ on the top and middle screens for the TMR and 24 and $40 \%$ on the top and middle screens for the orts). This indicates that the orts may have contained a slightly greater concentration of fiber than the diets fed, which may have resulted in an increase in fiber digestibility, had it been accounted for.

\section{Ruminal Concentrations of VFA}

Increased ruminal VFA concentrations were observed with the greatest level of urea supplementation (0.9\% urea diet; Table 4). Volatile fatty acids are the products of microbial fermentation of carbohydrates in the rumen; therefore, increased ruminal VFA concentrations are often assumed to be a result of increased fermentation of carbohydrates in the rumen. Because ruminal digestibility of carbohydrates was not affected by urea supplementation, an increase in ruminal VFA concentrations with the $0.9 \%$ urea diet was not expected.

Reported responses of ruminal concentrations of VFA to increasing ruminal ammonia $\mathrm{N}$ concentrations are inconsistent (Hume et al., 1970; Slyter et al., 1979; Griswold et al., 2003; Reynal and Broderick, 2005). Slyter et al. (1979) observed an increase in ruminal VFA concentrations when ruminal ammonia $\mathrm{N}$ concentrations of steers were increased from 2.2 to $4.5 \mathrm{mg} / \mathrm{dL}$, but did not observe a further increase at greater (up to $22.5 \mathrm{mg} / \mathrm{dL}$ ) ruminal ammonia $\mathrm{N}$ concentrations. The steers were fed a 30:70 forage:concentrate diet, and ammonia $\mathrm{N}$ concentrations were altered by continuous intraruminal infusions of different amounts of urea. Griswold et al. (2003) also observed an increase in total VFA concentrations in continuous culture when urea was added to the artificial saliva. Urea addition to the cultures resulted in increases in ammonia $\mathrm{N}$ concentrations from 0.26 to 6.01 and 0.21 to $6.11 \mathrm{mg} / \mathrm{dL}$. Although there is a difference in the range of observed ammonia N concentrations, the findings of Slyter et al. (1979) and Griswold et al. (2003) agree with those in the present experiment in that urea addition resulted in an increase in total VFA concentrations. Unlike the observations in the current experiment, Hume et al. (1970) found no 
differences in ruminal concentrations of total VFA when ruminal ammonia $\mathrm{N}$ concentrations were increased in sheep fed a protein-free purified diet 12 times daily. Reynal and Broderick (2005) observed a quadratic effect of dietary RDP concentrations on ruminal VFA concentrations. The ruminal ammonia N concentrations observed by Reynal and Broderick (2005) were $5.7,8.7,11.8$, and $12.3 \mathrm{mg} / \mathrm{dL}$ and total ruminal VFA concentrations were $92,86,81$, and $91 \mathrm{mM}$, respectively. Due to the differences described in the aforementioned studies regarding ruminal VFA concentrations in response to increasing ammonia $\mathrm{N}$ concentrations and the lack of an effect of urea supplementation on ruminal digestibility parameters in the present experiment, the increase in total ruminal VFA concentrations with increasing urea supplementation is difficult to explain. The differences in these reported observations could be due to differences in the fermentability of the diets fed, the experimental model used, and the manner in which ammonia $\mathrm{N}$ concentrations were altered (i.e., urea infusion, feeding urea and solvent SBM, etc.).

\section{In Situ Degradability}

There was no effect of increasing urea supplementation, and therefore increasing ruminal ammonia $\mathrm{N}$ concentrations, on in situ determined rates of degradation of corn silage, ground corn, or SBM in the present experiment (Table 5). The reported optimum ruminal ammonia $\mathrm{N}$ concentration required for maximum degradation rates of feedstuffs determined in situ varies within and among feedstuffs (Mehrez et al., 1977; Erdman et al., 1986; Odle and Schaeffer, 1987). Odle and Schaeffer (1987) observed that the optimum ruminal ammonia $\mathrm{N}$ concentration for maximum rate of degradation determined in situ for ground corn was $6.1 \mathrm{mg} / \mathrm{dL}$ in Holstein steers fed a cracked corn and ground corn cob diet supplemented with ammonium acetate hourly. If this value is correct, then a response in ruminal degradation rates of corn grain to greater ruminal ammonia $\mathrm{N}$ concentrations, as observed in the current experiment, would not be expected. In contrast, Erdman et al. (1986) observed that the optimum ruminal ammonia $\mathrm{N}$ concentration for maximum ED of DM, determined in situ, of corn grain and SBM was $25.0 \mathrm{mg} / \mathrm{dL}$ in nonlactating cows fed a diet containing $47 \%$ ground corn, $50 \%$ cottonseed hulls, and $3 \%$ vitamins and minerals twice daily. In that study (Erdman et al., 1986), urea was continuously infused into the rumen at $0,33,67$, and $100 \mathrm{~g} / \mathrm{d}$, which resulted in mean ruminal ammonia $\mathrm{N}$ concentrations of $4.3,10.1,17.2$, and $25.0 \mathrm{mg} / \mathrm{dL}$, respectively. Erdman et al. (1986) also determined that the ruminal ammonia $\mathrm{N}$ concentration required to maximize $\mathrm{ED}$ of $\mathrm{DM}$ for corn gluten feed and cottonseed meal was $17.0 \mathrm{mg} / \mathrm{dL}$.
Effective degradation of DM for alfalfa hay declined slightly with increasing ruminal ammonia $\mathrm{N}$ concentrations: $60.4,59.9,57.9$, and $58.0 \%$ for ruminal ammonia $\mathrm{N}$ concentrations of $4.3,10.1,17.2$, and $25.0 \mathrm{mg} / \mathrm{dL}$, respectively (Erdman et al., 1986). Although our data do not agree with the observations of Erdman et al. (1986), it has been suggested that the optimum ruminal ammonia $\mathrm{N}$ concentration for maximum EDDM is dependent on the fermentability of the diet fed, the chemical and physical structure of the feedstuff, the animal models used, and the method used to increase ruminal ammonia N concentrations (Erdman et al., 1986; Odle and Schaeffer, 1987). The diets fed in the current experiment, the animal model used, and the method of urea supplementation all varied between the present study and that of Erdman et al. (1986), which may explain the discrepancies between the results.

To our knowledge, the optimum ruminal ammonia $\mathrm{N}$ concentration required to maximize rate of degradation of corn silage has not been reported. Corn silage was the main forage ( $32 \%$ of diet DM; Table 1) in the basal diet fed in the present study; therefore, an effect of urea treatment on the ED of corn silage would likely have been reflected in differences in ruminal digestibility of diet DM, OM, and NDF. Indeed, there was no effect of urea supplementation on digestibility of diet DM, OM, and NDF or ED of DM and ED of NDF of corn silage (Tables 4 and 5).

\section{Microbial Protein Flow and Efficiency}

The 2 major dietary components that are required by ruminal microorganisms for synthesis of protein are fermentable carbohydrates and RDP. Because the carbohydrate composition of the diets was similar among dietary treatments (Table 2) and there was no effect of urea supplementation on ruminal digestibility of diet $\mathrm{OM}$ and $\mathrm{CHO}$ or ED of DM for corn silage, ground corn, or SBM, it is assumed that carbohydrate availability to the ruminal microorganisms was the same across diets. However, the amount of RDP increased with the addition of urea to the diets, and a quadratic effect of treatment on microbial protein flow and efficiency of microbial protein synthesis was observed with maximum responses at dietary RDP concentrations of 10.8 and $10.0 \%$ of DM, respectively (RDP concentration of control diet was $9.2 \%$ of diet DM). Therefore, it appears that ammonia $\mathrm{N}$, not availability of carbohydrates, was limiting microbial protein synthesis in the control diet. However, microbial protein synthesis was also limited by excessive ruminal ammonia $\mathrm{N}$ concentrations (17.4 $\mathrm{mg} / \mathrm{dL}$ ) when the $0.9 \%$ urea diet was fed. Considering these results, we conclude that the optimum ruminal ammonia $\mathrm{N}$ concentration required to support maxi- 
mum flow of microbial protein to the duodenum was $12.8 \mathrm{mg} / \mathrm{dL}$, and mean ruminal concentrations below $11.9 \mathrm{mg} / \mathrm{dL}$ and above $12.8 \mathrm{mg} / \mathrm{dL}$ may depress synthesis of microbial protein (Table 6) in the diet fed.

Kang-Meznarich and Broderick (1981) reported that $8.5 \mathrm{mg} / \mathrm{dL}$ of ammonia $\mathrm{N}$ in rumen fluid was sufficient for maximum content of microbial protein (measured by ruminal content of diaminopimelic acid) in the rumen of 2 nonlactating Holstein cows. Satter and Slyter (1974) determined the ammonia $\mathrm{N}$ requirements of mixed ruminal bacteria for microbial protein synthesis in continuous culture using a variety of substrate mixtures and tungstic acid-precipitable- $\mathrm{N}$ as a marker for microbial protein. The authors observed that an ammonia $\mathrm{N}$ concentration of $5.0 \mathrm{mg} / \mathrm{dL}$ was adequate to support maximum growth rates of rumen bacteria; however, they also noted that the precise limiting ammonia $\mathrm{N}$ concentration was closer to $2.0 \mathrm{mg} / \mathrm{dL}$. Slyter et al. (1979) observed that concentrations of tungstic acid-precipitable-N, used to estimate changes in ruminal concentrations of microbial protein, were maximized at a ruminal ammonia $\mathrm{N}$ concentration of $2.2 \mathrm{mg} / \mathrm{dL}$. Concentrations of tungstic acid-precipitable- $\mathrm{N}$ were not increased at greater ruminal ammonia $\mathrm{N}$ concentrations up to 22.5 $\mathrm{mg} / \mathrm{dL}$. In these studies, urea was either infused continuously or fed hourly, which would result in more stable ruminal ammonia $\mathrm{N}$ concentrations than are normally observed in lactating cows. In the present experiment, ruminal ammonia $\mathrm{N}$ concentrations fluctuated in response to time of feeding, which resulted in major changes in ruminal ammonia $\mathrm{N}$ concentrations within treatments over a 24 -h period (Figure 1). It is possible that if the ammonia $\mathrm{N}$ concentration were more stable, then the mean ammonia $\mathrm{N}$ concentration required by the microorganisms to maximize synthesis of microbial protein would be reduced due to a constant availability of a $\mathrm{N}$ source. However, a ruminal ammonia $\mathrm{N}$ pattern similar to that observed in the current experiment would be expected in practical feeding situations when TMR are fed.

Reynal and Broderick (2005) fed diets varying in RDP concentrations $(7.7,9.2,10.9$, and $12.5 \%$ of diet $\mathrm{DM})$ to lactating cows with urea mixed into the TMR. The diets were fed twice daily, which is more similar to the feeding regimen used in the present experiment. They observed a linear increase in microbial NAN flow to the omasal canal in response to increasing dietary RDP. The greatest concentration of RDP fed was $12.6 \%$ of diet $\mathrm{DM}$ and corresponded to the greatest observed mean ruminal ammonia $\mathrm{N}$ concentration of $12.3 \mathrm{mg} / \mathrm{dL}$ (Reynal and Broderick, 2005). In the current experiment, the greatest dietary RDP concentration fed was $11.6 \%$ of diet DM; however, the greatest mean ruminal ammonia $\mathrm{N}$ concentration was $17.4 \mathrm{mg} / \mathrm{dL}$. Reynal and Brod- erick (2005) increased dietary RDP concentrations by the addition of a combination of urea and true protein (from solvent SBM), whereas in the present study, RDP concentrations were increased solely by increasing dietary inclusion rates of urea. The difference between the 2 studies in RDP source may explain the differences in ruminal ammonia $\mathrm{N}$ concentrations observed at similar RDP levels. Soybean meal provides a mixture of AA, peptides, and ammonia, whereas urea provides only ammonia. The differences in the observed maximum mean ruminal ammonia $\mathrm{N}$ concentrations in the present study and those observed by Reynal and Broderick (2005) may also explain why they observed a linear increase in microbial protein flow, whereas we observed a quadratic effect on microbial protein flow. KangMeznarich and Broderick (1981) observed that bacterial CP yields (estimated from ruminal diaminopimelic acid concentrations) appeared to be lower at ruminal ammonia $\mathrm{N}$ concentrations above $13.8 \mathrm{mg} / \mathrm{dL}$, which supports the findings in the current study. It is possible that the ruminal ammonia $\mathrm{N}$ concentrations observed by Reynal and Broderick (2005) were not high enough (greatest: $12.3 \mathrm{mg} / \mathrm{dL}$ ) to detect a quadratic response of microbial protein flow to the omasum, as was observed in the current study and by Kang-Meznarich and Broderick (1981).

Microbial efficiency expressed as grams of microbialN/kilogram of OMTD, grams of microbial-N/kilogram of CHOTD, grams of microbial-N/kilogram of DMI, and grams of microbial-N/gram of RDP-N was maximized in the present experiment at an average ruminal ammonia N concentration of $11.9 \mathrm{mg} / \mathrm{dL}$ ( $0.3 \%$ urea supplementation) and was lowest at the ruminal ammonia $\mathrm{N}$ concentration of $17.4 \mathrm{mg} / \mathrm{dL}$ (0.9\% urea supplementation; Table 6). Based on a review of experimental data, Robinson (1996) reported that microbial efficiency ( $g$ of microbial N/kg of DMI) declines when ruminal ammonia $\mathrm{N}$ concentrations increase above $11.0 \mathrm{mg} / \mathrm{dL}$. In the current experiment, microbial efficiency expressed as grams of microbial N/kilogram of DMI only declined when the mean ruminal ammonia $\mathrm{N}$ concentration was $17.4 \mathrm{mg} / \mathrm{dL}$ (Table 6). However, based on the mean ruminal ammonia $\mathrm{N}$ and microbial efficiency values that we observed, we conclude that the mean ruminal ammonia $\mathrm{N}$ concentrations required to maximize microbial efficiency would range from 11 to $13 \mathrm{mg} / \mathrm{dL}$. KangMeznarich and Broderick (1981) calculated bacterial efficiency as grams of microbial-N/100 kilograms of DM digested and, although numerically, bacterial efficiency was lower at ruminal ammonia $\mathrm{N}$ concentrations below $8.5(1.3$ and $3.3 \mathrm{mg} / \mathrm{dL})$ and above $13.8 \mathrm{mg} / \mathrm{dL}$ (22.8 and $28.9 \mathrm{mg} / \mathrm{dL}$ ), the differences were not significant. KangMeznarich and Broderick (1981) speculated that these measurements lacked clear statistical inference due to 
the variability in other parameters used to compute bacterial efficiency.

\section{Passage of AA to the Duodenum and Plasma AA Concentrations}

Passage of AA to the duodenum was measured in the current experiment; however, the data are not presented because there were no treatment effects on these measurements or on the profile of AA in duodenal digesta. Although there was a quadratic effect of treatment on flow of microbial protein to the duodenum in the present experiment, flow of NAN was not affected by urea supplementation (Table 6). Therefore, microbial $\mathrm{N}$ as a percentage of NAN increased with 0.3 and $0.6 \%$ urea supplementation, and NANMN as a percentage of NAN decreased with 0.3 and $0.6 \%$ urea supplementation. Because NAN flow to the duodenum was not affected by treatment, an increase in AA flow would also not be expected. Reynal and Broderick (2005) also observed an increase in flow of microbial protein to the omasum when diets with increasing RDP concentrations were fed to lactating cows, but did not observe an effect on flow of total AA to the omasum.

Although there was no effect of urea supplementation on flow of AA to the duodenum, there was a quadratic effect of treatment on total plasma AA concentrations (Table 7). There was a trend $(P=0.10)$ for a quadratic effect of urea treatment on plasma concentrations of arginine and a significant quadratic effect of treatment on threonine and citrulline concentrations. The greatest concentrations were observed at ruminal ammonia $\mathrm{N}$ concentrations of 9.0 and $17.4 \mathrm{mg} / \mathrm{dL}$. Slyter et al. (1979) observed that urea supplementation of a corn and hay diet decreased plasma concentrations of threonine and increased plasma concentrations of arginine and citrulline in steers. In that study (Slyter et al., 1979), ruminal ammonia $\mathrm{N}$ concentrations observed ranged from 1.1 to $22.5 \mathrm{mg} / \mathrm{dL}$. The changes in plasma concentrations of the aforementioned AA were observed when ruminal ammonia $\mathrm{N}$ concentrations increased from 1.1 to $2.2 \mathrm{mg} / \mathrm{dL}$ (Slyter et al., 1979). Changes in other plasma AA concentrations were not observed at greater ruminal ammonia $\mathrm{N}$ concentrations. Changes in plasma AA concentrations of threonine in this study were not expected; however, arginine and citrulline are intermediates in the urea cycle, so changes in plasma concentrations of these AA with increasing ruminal ammonia $\mathrm{N}$ concentrations were expected. Capture of ammonia $\mathrm{N}$ by rumen microbes as determined by flow of microbial protein and microbial efficiency was also lowest with 0 and $0.9 \%$ urea supplementation, which might have affected urea cycle activity.

\section{Milk Components}

Production responses to varying concentrations of ammonia $\mathrm{N}$ in ruminal digesta were not expected because late-lactation animals were used in the current study. Indeed, increasing urea supplementation did not affect milk yield, milk true protein yield, milk fat yield and concentration, or the efficiency of conversion of feed to milk (Table 8). However, the efficiency of conversion of feed $\mathrm{N}$ to milk $\mathrm{N}$ decreased with increasing urea supplementation. This response was expected because RDP requirements (NRC, 2001) were exceeded with the 0.6 and $0.9 \%$ urea diets (Table 2).

An inverse relationship between milk true protein (decreased linearly) and MUN (increased linearly) concentrations was observed in the current experiment with increasing urea supplementation. This finding is supported by Johnson and Young (2003), who observed an inverse relationship between MUN concentrations and milk true protein concentrations when DHI records for western commercial dairy herds were analyzed. Concentrations of MUN were expected to increase because CP concentrations of the diets increased. The direct relationship between MUN and dietary CP concentrations is well documented (Frank and Swensson, 2002; Nousiainen et al., 2004).

\section{CONCLUSIONS}

The optimum ruminal ammonia $\mathrm{N}$ concentration required to support maximum ruminal digestibility of diet OM or ED of DM of feedstuffs when a corn silagebased diet is fed to lactating cows appears to be lower than the ruminal ammonia $\mathrm{N}$ concentration required to support maximum synthesis of microbial protein. The optimum ruminal ammonia $\mathrm{N}$ concentration required to support maximum synthesis of microbial protein and maximum efficiency of microbial protein synthesis when a corn silage-based diet is fed to lactating cows was determined to be between 11 and $13 \mathrm{mg} / \mathrm{dL}$, achieved when dietary RDP concentrations were 10.0 and $10.8 \%$ of diet DM and dietary urea concentrations were 0.3 and $0.6 \%$. It appears that without dietary inclusion of supplemental urea, ruminal ammonia $\mathrm{N}$ concentrations limited microbial protein synthesis, but did not limit diet digestibility. Adding urea to a corn silagebased diet such that RDP requirements (NRC, 2001) exceed $110 \%$ may depress microbial protein synthesis.

\section{ACKNOWLEDGMENTS}

The authors would like to thank Glen Broderick for analysis of rumen fluid for total free amino acid concentration and Gabriella Varga and Terri Cassidy for analysis of rumen fluid for volatile fatty acid concentrations. 
We would also like to thank the staff at the Fairchild Dairy Teaching and Research Center (Durham, NH) for feeding and caring for the animals.

\section{REFERENCES}

AOAC. 2000. Official Methods of Analysis. 19th ed. Association of Official Analytical Chemists, Washington, DC.

Balcells, J., J. A. Guada, C. Castrillo, and J. Gasa. 1993. Rumen digestion and urinary excretion of purine derivatives in response to urea supplementation of sodium-treated straw fed to sheep. Br. J. Nutr. 69:721-723.

Erdman, R. A., G. H. Proctor, and J. H. Vandersall. 1986. Effect of rumen ammonia concentration on in situ rate and extent of digestion of feedstuffs. J. Dairy Sci. 69:2312-2320.

Frank, B., and C. Swensson. 2002. Relationship between content of crude protein in rations for dairy cows and milk yield, concentration of urea in milk, and ammonia emissions. J. Dairy Sci. 85:1829-1838.

Griswold, K. E., G. A. Apgar, J. Bouton, and J. L. Firkins. 2003. Effects of urea infusion and ruminal degradable protein concentration on microbial growth, digestibility, and fermentation in continuous culture. J. Anim. Sci. 81:329-336.

Heinrichs, J. 1996. Evaluating particle size of forages and TMRs using the Penn State particle size separator. DAS 96-20. Coll. Agri. Sci., Pennsylvania State Univ., University Park.

Holter, J. B., N. F. Colovos, H. A. Davis, and W. E. Urban, Jr. 1968 Urea for lactating dairy cattle. III. Nutritive value of rations of corn silage plus concentrate containing various levels of urea. J. Dairy Sci. 51:1243-1248.

Hume, I. D., R. J. Moir, and M. Somers. 1970. Synthesis of microbial protein in the rumen. I. Influence of the level of nitrogen intake. Aust. J. Agric. Res. 21:283-296.

Johnson, R. G., and A. J. Young. 2003. The association between milk urea nitrogen and DHI production variables in western commercial dairy herds. J. Dairy Sci. 86:3008-3015.

Jones, D. F., W. H. Hoover, and T. K. Miller. 1998. Effects of concentrations of peptides on microbial metabolism in continuous culture. J. Anim. Sci. 76:611-616.

Kang-Meznarich, J. H., and G. A. Broderick. 1981. Effects of incremental urea supplementation on ruminal ammonia concentration and bacterial protein formation. J. Anim. Sci. 51:422-431.

Lykos, T., and G. A. Varga. 1995. Effects of processing method on degradation characteristics of protein and carbohydrate sources in situ. J. Dairy Sci. 78:1789-1801.

Makkar, H. P., and K. Becker. 1999. Purine quantification in digesta from ruminants by spectrophotometric HPLC methods. Br. J. Nutr. 81:107-118.

Mehrez, A. Z., E. R. Ørskov, and I. McDonald. 1977. Rates of rumen fermentation in relation to ammonia concentration. Br. J. Nutr. 38:437-443.
NRC. 2001. Nutrient Requirements of Dairy Cattle. 7th rev. ed. Natl. Acad. Sci. Washington, DC.

Nousiainen, J., K. J. Shingfield, and P. Huhtanen. 2004. Evaluation of milk urea nitrogen as a diagnostic of protein feeding. J. Dairy Sci. 87:386-398.

Odle, J., and D. M. Schaeffer. 1987. Influence of rumen ammonia concentration on the rumen degradation rates of barley and maize. Br. J. Nutr. 57:127-138.

Ørskov, E. R., and I. McDonald. 1979. The estimation of protein degradability in the rumen from incubation measurements weighted according to rate of passage. J. Agric. Sci. (Camb.) 92:499-503.

Poos, M. I., L. S. Bull, and R. W. Hemken. 1979. Supplementation of diets with positive and negative urea fermentation potential using urea or soybean meal. J. Anim. Sci. 49:1417-1426.

Putnam, D. E., C. G. Schwab, M. T. Socha, N. L. Whitehouse, N. A. Kierstead, and B. D. Garthwaite. 1997. Effect of yeast culture in the diets of early lactation dairy cows on ruminal fermentation and passage of nitrogen fractions and amino acids to the small intestine. J. Dairy Sci. 80:374-384.

Reynal, S. M., and G. A. Broderick. 2005. Effect of dietary level of rumen-degraded protein on production and nitrogen metabolism in lactating dairy cows. J. Dairy Sci. 88:4045-4064.

Robinson, P. H. 1996. Rumen protein metabolism-Predicting outflow. Page 40 in Proc. Eastern Nutr. Conf. Canadian Feed Industry Assoc., Ottawa, Ontario, Canada.

Roth, M. 1971. Fluorescence reaction of amino acids. Anal. Chem. 43:880-882.

SAS Institute. 2001. SAS/STAT User's Guide. Version 8 ed. SAS Inst. Cary, NC.

Satter, L. D., and L. L. Slyter. 1974. Effect of ammonia concentration on rumen microbial protein production in vitro. Br. J. Nutr. 32:199-208.

Schwab, C. G., C. K. Bozak, N. L. Whitehouse, and M. M. Mesbash. 1992. Amino acid limitation and flow to the duodenum at four stages of lactation. J. Dairy Sci. 75:3486-3502.

Slyter, L. L., L. D. Satter, and D. A. Dinius. 1979. Effect of ruminal ammonia concentration on nitrogen utilization by steers. J. Anim. Sci. 48:906-912.

Van Horn, H. H., D. R. Jacobson, and A. P. Graden. 1969. Influence of level and source of nitrogen on milk production and blood components. J. Dairy Sci. 52:1395-1403.

Whitehouse, N. L., V. M. Olson, C. G. Schwab, W. R. Chesbro, K. D. Cunningham, and T. Lykos. 1994. Improved techniques for dissociating particle-associated mixed ruminal microorganisms from ruminal digesta solids. J. Anim. Sci. 72:1335-1343.

Williams, C. H., D. J. David, and O. Iismaa. 1962. The determination of chromic oxide in faeces samples by atomic absorption spectrophotometry. J. Agric. Sci. 59:381-385.

Yang, C. M. J., and G. A. Varga. 1989. Effect of three concentrate feeding frequencies on rumen protozoa, rumen digesta kineticorn silage, and milk yield in dairy cows. J. Dairy Sci. 72:950-957.957. 